\title{
Oea
}

JURNAL PENDIDIKAN GEOGRAFI

\section{PENGARUH PENGGUNAAN MEDIA INTERAKTIF TERHADAP HASIL BELAJAR DAN SIKAP CINTA TANAH AIR PESERTA DIDIK}

\author{
${ }^{1}$ Yayah Suhayah, ${ }^{2}$ Enok Maryani, ${ }^{3}$ Ahmad Yani \\ ${ }^{1}$ SMP Negeri 31 Bandung Jawa Barat, e-mail: y ay ahshy @ gmail.com \\ ${ }^{2}$ Jurusan Pendidikan Geografi, FPIPS, UPI, email: emaryani@yahoo.com \\ ${ }^{3}$ Jurusan Pendidikan Geografi, FPIPS, UPI, email: ahy ani_07@y ahoo.co.id
}

\begin{abstract}
Phenomenon of low grades as learning outcomes, the lack of patriotic attitudes, and lack of sen se of communal unity displayed by students that led to social disintegration, had been the background issue for this research. Monotonous teaching method and the lack of interactive learning media had led to students' less trained thinking skill capacity, which overall took effect on learning outcomes. In order to overcome these issues, the use of interactive media as teaching method was proposed in contrary to conventional image media. To measure the effect of the use of interactive media teaching method towards students' learning outcomes and patriotic attitudes, a direct experimental approach by means of case study was conducted. Sixty students of Class VIII of SMPN 31 Bandung were chosen as the subject of research. Experimental research method was employed with several data collecting methods such as testing (pre-test and post-test) and non testing method (Likert scale in attitudes category measure). The collected data was analyzed by the means of T-test, normality test and homogeneity, and with the help of statistic analysis software namely SPSS version 17.0. Analysis results demonstrated that: (1) there was no significant difference of students' pre-test results between interactive media class and conventional image media class. (2) There was significant difference of students' post-test results between interactive media class and image media class. (3) There was significant difference of students' pre-test results as well as post-test results in both interactive media class and image media class. (4) There was significant difference of patriotic attitude assessment result between pre-test and post-test, in students with interactive media method and image media method. Other difficulties found during the experiment were limited learning time and the fact that some of the students who made use of the internet for another browsing activity during the interactive media class.
\end{abstract}

Keywords: Interactive media, learning outcomes, patriotic attitude

\begin{abstract}
ABSTRAK
Latar belakang penelitian adalah hasil belajar yang rendah, kurang rasa cinta tanah air, hilang rasa persatuan peserta didik bahkan mengarah kepada perpecahan. Penggunaan metode mengajar yang monoton, kurangnya media pembelajaran interaktif yang berakibat kemampuan berpikir siswa kur an $g$ terlatih dan berdampak pada hasil belajarnya. Perlu dilakukan berbagai upaya, salah satunya adalah menggunakan media pembelajaran interaktif. Subjek penelitian siswa Kelas VIII SMPN 31 Ban dung berjumlah 60 siswa. Metode penelitian menggunakan eksperimen. Pengumpulan data den gan teknik tes (pretes, postes), dan non tes (skala sikap kategori Likert). Teknik pengolahan data adalah Uji T, Uji normalitas, dan homogenitas dengan bantuan program SPSS versi 17,0. Hasil analisis data menunjukkan 1) tidak terdapat perbedaan yang signifikan terhadap hasil pre-tes siswa antara kelas yang menggunakan media interaktif dengan kelas yang menggunakan media gambar 2) terdapat perbedaan signifikan terhadap hasil pos-test siswa antara kelas yang menggunakan media interaktif dengan kelas yang menggunakan media gambar 3) terdapat perbedaan signifikan terhadap hasil pre test dan posttest siswa yang menggunakan media interaktif yang menggunakan media gambar, 4) terdapat perbedaan signifikan sikap cinta tanah air peserta didik antara pre-tes dan post-tes siswa y ang menggunakan media interaktif dengan siswa yang menggunakan media gambar. Adapun kendala yang
\end{abstract}


dihadapi adalah waktu yang kurang cukup dan masih ada siswa yang membuka situs lain ketika pembelajaran interaktif berlangsung.

Kata kun ci: Media Interaktif, Hasil Belajar, Sikap Cinta T anah Air.

\section{PENDAHULUAN}

Media pembelajaran dalam proses belajar mengajar dapat membangkitkan keinginan dan minat yang baru, membangkitkan motivasi dan rangsangan kegiatan belajar dan bahkan membawa pengaruh-pengaruh psikologis terhadap siswa. Hamalik (1986: 6). Media interaktif merupakan media berbasis komputer yang terdiri atas teks, grafik, audio, dan video yang dibuat, dikemas, disajikan, dan dimanfaatkan secara interaktif melalui komputer. Dengan demikian dapat dikatakan bahwa media pembelajaran interaktif adalah presentasi yang menggunakan kombinasi grafik, teks, suara, video, dan atau animasi sehingga penggabungan ini merupakan suatu kesatuan yang dapat menampilkan informasi, pesan atau isi pelajaran serta mampu mengolah informasi dan memberikan umpan balik seketika berupa informasi baru kepada pengguna. Sebuah media yang menegaskan format multimedia dapat dikemas dalam sebuah CD (Compact Disk) dengan tujuan aplikasi interaktif di dalamnya.

Dengan menggunakan media interaktif dalam penelitian ini diharapkan memberikan pengalaman yang menyenangkan, mengingat pembelajaran dengan media interaktif cukup menarik dan memicu minat untuk lebih bersemangat dalam mengikuti pelajaran dan peserta didik dapat berinteraksi secara aktif, sehingga hasil belajarny a memuaskan dan pada akhirnya meningkatkan kualitas pembelajaran secara keseluruhan.

Menurut Hamalik (1999: 159), hasil belajar menunjukkan pada prestasi belajar, sedangkan prestasi belajar itu merupakan indikator adanya perubahan tingkah laku peserta didik. Hasil belajar merupakan penguasaan peserta didik terhadap berbagai pengetahuan, keterampilan dan sikap yang diperoleh peserta didik setelah mengikuti proses belajar. Sedangkan Sikap merupakan pembawaan yang dapat dipelajari dan dapat mempengaruhi perilaku seseorang terhadap benda, kejadian-kejadian, atau mahluk hidup lainnya. Dahar (2006: 123)

Cinta tanah air adalah perasaan yang timbul dari dalam hati sanubari seorang warga negara terhadap tempat kelahiran atau tanah airnya untuk mengabdi, memelihara, membela, melindungi tanah airnya dari segala ancaman dan gangguan. (Sisdiknas, 2010: 35). Kementrian Pendidikan Nasional Balitbang (2010: 10) mencantumkan nilai karakter yang terdapat dari cinta tanah air adalah: "Cara berfikir, bersikap dan berbuat yang menunjukkan kesetiaan, kepedulian dan penghargaan y ang tinggi terhadap bahasa, lingkungan fisik, sosial, budaya, ekonomi dan politik bangsa. Rasa cinta tanah air, rasa persatuan dan kesatuan, akan berkembang setelah peserta didik memiliki pengetahuan dan pemahaman tentang berbagai potensi dan masalah negara. Mengingat begitu pentingnya peranan pelajaran geografi, maka perlu disajikan dalam bentuk imajinatif, menarik dan meny enangkan. Maryani (2009: 5)

Menurut Su'ud (2006: 3) Kondisi fisik wilayah Indonesia amat unik, dengan kultur maupun sistem sosial yang beraneka ragam sangat rawan terhadap rusaknya tatanan sosial y ang integratif. Gejala tersebut meliputi erosi nilai kebangsaan, disintegrasi sosial, sparatisme maupun rasialisme.

Selain hasil belajar yang masih rendah, ada kekhawatiran dari peneliti terhadap sikap peserta didik yang mengarah kepada perpecahan dan kurangnya rasa cinta tanah air, sebagai contoh dengan maraknya tawuran antar pelajar. Hal ini diduga terjadi akibat semangat persatuan dan kesatuan y ang sudah memudar dan mudahnya terpengaruh oleh hal-hal yang bersifat menghasut sehingga menimbulkan permusuhan. Demikian juga hasil wawancara dengan beberapa guru IPS y ang merasa kesulitan ketika mengajarkan materi ini hany a dengan berupa teks atau gambar. Hal tersebut mendorong penulis untuk mengadakan penelitian yang dituangkan dalam judul "Pengaruh Penggunaan Media Interaktif Terhadap Hasil Belajar dan Sikap Cinta Tanah Air Peserta Didik" (Eksperimen di Kelas VIII SMPN 31 Bandung). 
Berdasarkan latar belakang, rumusan masalah dalam penelitian adalah : 1) Apakah terdapat perbedaan yang signifikan antara hasil belajar di kelas eksperimen dan di kelas kontrol sebelum menggunakan media interaktif dan media gambar ? 2) Apakah terdapat perbedaan yang signifikan antara hasil belajar sebelum dan sesudah pembelajaran di kelas y ang menggunakan media interaktif dengan kelas yang menggunakan media gambar ? 3) Bagaimanakah sikap cinta tanah air peserta didik sebelum dan sesudah pembelajaran di kelas y ang menggunakan media interaktif dan di kelas yang menggunakan media gambar ?

Tujuan dari penelitian ini adalah 1) Mengetahui perbedaan antara hasil belajar sebelum pembelajaran di kelas yang menggunakan media interaktif dan di kelas yang menggunakan media gambar. 2) Mengetahui perbedaan antara hasil belajar sebelum dan sesudah pembelajaran di kelas yang menggunakan media interaktif dan di kelas yang menggunakan media gambar. 3) Mengetahui perbedaan sikap cinta tanah air sebelum dan sesudah pembelajaran di kelas yang menggunakan media interaktif dan di kelas yang menggunakan media gambar.

\section{METODE PENELITIAN}

Metode yang digunakan dalam penelitian ini eksperimen. Desain eksperimen yang digunakan dalam penelitian ini adalah eksperimen semu (Quasi Eksperimen). Metode ini merupakan metode penelitian y ang pengontrolanny a hanya dilakukan terhadap satu variabel saja yaitu variabel yang dipandang paling dominan.(Sukmadinata, 2011 : 59). Metode eksperimen ini digunakan mengingat karakteristik variabel penelitian yang bersifat ingin mengetahui informasi terhadap suatu media yang diterapkan, yaitu bagaimana perbedaan hasil belajar peserta didik y ang menggunakan media interaktif dengan hasil belajar peserta didik yang tidak menggunakan media interaktif pada materi Kondisi fisik wilay ah Indonesia di kelas VIII.

Populasi penelitian adalah seluruh peserta didik kelas VIII di SMP Negeri 31 Kota Bandung Propinsi Jawa Barat yang terdiri dari kelas VIII - 1, VIII - 2, VIII - 3, VIII - 4, VIII - 5. Dan VIII - 6. Sedangkan sampel penelitian dilakukan terhadap dua kelas yang mempunyai karakteristik yang sama berdasarkan skor nilai ulangan yang telah dilakukan sebelumnya.

\section{HAS IL DAN PEMBAHAS AN}

\section{Hasil Penelitian}

Deskripsi hasil penelitian ini menjelaskan tentang bagaimana pengaruh penggunaan media interaktif dan media gambar terhadap hasil belajar dan sikap cinta tanah air peserta didik pada pembelajaran kondisi fisik wilayah Indonesia

Pada penelitian ini melakukan pre-test terhadap peserta didik di kelas eksperimen, sebelum mendapat pembelajaran dengan menggunakan media interaktif. Tes yang diberikan kepada peserta didik merupakan alat tes berbentuk pilihan ganda sebanyak 25 soal. Perolehan nilai pre-test hasil belajar peserta didik dengan rentang nilai pada kelas eksperimen yang tertinggi 80,00 dan terendah 36,00, sehingga perolehan hasil pre-test masih banyak yang di bawah KKM 72,00.

Hasil post-test diperoleh setelah siswa di kelas eksperimen mendapatkan perlakuan pembelajaran dengan menggunakan media interaktif. Proses pelaksanaan di kelas eksperimen sebanyak tiga kali pertemuan dengan alokasi waktu 2 x 40 menit untuk setiap pertemuan.

Tabel 1. Nilai Rata-rata Pre-test dan Post-test Kelompok Eksperimen

\begin{tabular}{lcc}
\hline Statistik Deskriptif & Pre-tes & Post-tes \\
\hline Nilai rata-rata & 55,5 & 84,10 \\
\hline Nilai Terendah & 36,00 & 64,00 \\
\hline Nilai tertinggi & 80,00 & 100 \\
\hline
\end{tabular}


Data pada Tabel 1 menunjukkan terjadinya perubahan hasil belajar peserta didik, walaupun masih ada peserta didik yang mendapat nilai di bawah KKM yaitu sebanyak 3 orang, akan tetapi perolehan nilai dari pre-test ke nilai post-test terjadi peningkatan yang cukup besar. Hal ini dapat dilihat pada tabel di atas dengan peningkatan nilai rata-rata 55,5 pada pre-test menjadi 84,10 pada post-test.

Pada penelitian ini melakukan pre-test terhadap peserta didik di kelas kontrol sebelum mendapat pembelajaran dengan menggunakan media gambar. Tes yang diberikan kepada peserta didik merupakan alat tes berbentuk pilihan ganda sebanyak 25 soal. Perolehan nilai pre-test hasil belajar peserta didik dengan rentang nilai pada kelas kontrol yang tertinggi 72,00 dan terendah 36,00, sehingga perolehan hasil pre-test masih banyak yang di bawah KKM y aitu 72,00.

Hasil post-test diperoleh setelah siswa di kelas kontrol mendapatkan perlakuan pembelajaran dengan menggunakan media gambar. Proses pelaksanaan di kelas kontrol sebanyak tiga kali pertemuan dengan alokasi waktu 2 x 40 menit untuk setiap pertemuan.

Tabel 2. Nilai Rata-rata Pre-test dan Post-test Kelompok Kontrol

\begin{tabular}{lcc}
\hline Statistik Deskriptif & Pretes & Posttes \\
\hline Nilai rata-rata & 55,6 & 76,5 \\
\hline Nilai Terendah & 36,00 & 68,00 \\
\hline Nilai tertinggi & 64,00 & 100 \\
\hline
\end{tabular}

Data pada Tabel 2 dapat disimpulkan bahwa setelah pembelajaran dengan menggunakan media gambar pada kelompok kontrol hasil belajarny a meningkat. Hal ini dapat dilihat pada tabel di atas dengan peningkatan nilai rata-rata 55,6 pada pre-test menjadi 76,5 pada post-test. Dari datatersebut disimpulkan bahwa hasil post-test lebih tinggi daripada pre-test.

Untuk mengetahui ada atau tidaknya peningkatan hasil belajar peserta didik pada kelompok eksperimen dan kelompok kontrol, maka harus dilakukan uji Gain Ternormalisasi (normalized gain) Meltzer dalam Sagita, A (2011:51).

Tabel 3. Uji Gain Hasil Belajar Kelas Eksperimen dan Kelas Kontrol

\begin{tabular}{ccccc}
\hline \multirow{2}{*}{ Kelompok } & \multicolumn{3}{c}{ Gain ternormalisasi } & $\begin{array}{c}\text { Rata-rata gain } \\
\text { ternormalisasi }\end{array}$ \\
\cline { 2 - 4 } & $\begin{array}{c}<0,3 \\
\text { Rendah }\end{array}$ & $\begin{array}{c}3<\mathrm{g}<0,7 \\
\text { Sedang }\end{array}$ & $\begin{array}{c}>0,7 \\
\text { Tinggi }\end{array}$ & 0,53 \\
\hline Eksperimen & 6 & 15 & 9 & 0,48 \\
\hline Kontrol & 1 & 26 & 3 & \\
\hline
\end{tabular}

Hasil uji gain ternormalisasi menunjukkan terjadinya peningkatan dengan rata-rata nilai gain yang ternormalisasi 0,53 pada kelompok eksperimen. Nilai gain yang ternormalisasi pada kelompok kontrol rata-rata nilai adalah 0,48 . Data menunjukkan gain ternormalisasi pada peserta didik kategori tinggi lebih banyak pada kelompok eksperimen dari pada kelompok kontrol. Rata-rata secara keseluruhan juga memperlihatkan nilai yang lebih baik pada kelompok eksperimen yaitu 0,53 (kategori sedang) dibanding dengan kelompok kontrol y aitu 0,48 (kategori sedang).

Identifikasi peserta didik dilihat dari sikap cinta tanah air pada pembelajaran dengan menggunakan media Interaktif dan peserta didik yang menggunakan media gambar dalam pembelajaran Kondisi fisik wilayah Indonesia dapat dijelaskan sebagaimana tertera pada Tabel 4. 
Tabel. 4. Sikap Cinta Tanah Air Pada Kelas Eksperimen dan Kelas Kontrol

\begin{tabular}{lcccc}
\hline Statistik Deskriptif & \multicolumn{2}{c}{ Kelas Eksperimen } & \multicolumn{2}{c}{ Kelas Kontrol } \\
\hline & Pre Test & Post Test & Pre Test & Post Test \\
\hline Nilai rata-rata & 65,37 & 86,27 & 65,67 & 74,20 \\
\hline Modus Nilai & 66,00 & 84,00 & 64,70 & 76,00 \\
\hline Standar Deviasi & 6,815 & 6,596 & 6.451 & 6.127 \\
\hline Variansi Nilai & 92,257 & 128,783 & 42,672 & 65,007 \\
\hline
\end{tabular}

Hasil uji sikap cinta tanah air peserta didik dapat disimpulkan bahwa terjadi peningkatan yang signifikan dari perolehan nilai rata-rata pre-test 65,37 ke nilai rata-rat posttest 86,27 pada kelompok eksperimen, begitu juga terjadi peningkatan y ang signifikan pada nilai rata-rata pre-test kelompok kontrol 65,67 ke nilai post-test menjadi 74,20 . Tetapi jika dibandingkan peningkatan nilai pre-test ke nilai post-test pada kelompok eksperimen yang menggunakan media interaktif lebih besar dari nilai pre-test ke nilai post test pada kelompok kontrol y ang menggunakan media gambar.

\section{Pelaksanaan Pembelajaran}

Pelaksanaan pembelajaran baik pada kelompok eksperimen yang menggunakan media interaktif maupun kelompok kontrol yang menggunakan media gambar dilakukan melalui kinerja berkelompok. Belajar berkelompok merupakan salah satu cara belajar yang efektif untuk meningkatkan aktivitas peserta didik menurut Nasution , 1995 (dalam Widiyati Ana, 2011) adalah (1) mempertinggi hasil belajar baik secara kuantitatif atau kualitatif, (2) keputusan kelompok lebih mudah diterima, (3) mengembangkan perasaan sosial dan pergaulan sosial yang baik, (4) individu dalam kelompok saling membantu mengkoreksi kesalahan, toleransi, dan membangkitkan minat.

Hasil keterlaksanaan pembelajaran pada kelompok eksperimen dari setiap pertemuan dapat dilihat pada tabel 5 . berikut.

Tabel 5.. Keterlaksanaan RPP pada Tiap-tiap Pertemuan di Kelompok Eksperimen

\begin{tabular}{|c|c|c|c|c|c|}
\hline \multirow[b]{2}{*}{ No } & \multirow{2}{*}{$\begin{array}{l}\text { Aspek yang } \\
\text { diobservasi }\end{array}$} & \multicolumn{2}{|c|}{ Skor keterlaksanaan media } & \multirow{2}{*}{$\begin{array}{l}\text { Skor Rata- } \\
\quad \text { rata\% }\end{array}$} & \multirow[b]{2}{*}{ Kategori } \\
\hline & & $\begin{array}{c}\text { Aktivitas Peserta } \\
\text { didik \% }\end{array}$ & $\begin{array}{l}\text { Aktivitas } \\
\text { Guru\% }\end{array}$ & & \\
\hline 1 & RPP 1 & 72 & 79 & 76 & Baik \\
\hline 2 & $\overline{\mathrm{RPP}} 2$ & 80 & $\overline{76}$ & $\overline{79}$ & $\overline{\text { Baik }}$ \\
\hline 3 & RPP 3 & 82 & 83 & 82 & Baik \\
\hline
\end{tabular}

Keterlaksanaan pembelajaran dengan menggunakan media interaktif secara umum termasuk dalam kategori baik, yaitu pada pertemuan $172 \%$ meningkat pada pertemuan II menjadi $80 \%$, meningkat lagi pada pertemuan ke III menjadi $82 \%$. Sedangkan aktivitas guru pada pertemuan I $79 \%$,pertemuan II menurun menjadi $76 \%$, namun pada pertemuan ke III meningkt Lgi menjadi $83 \%$. Dengan adanya peningkatan persentase keterlaksanaan RPP dari setiap pertemuan aktivitas peserta didik dan guru dalam pembelajaran ini terjadi karena faktor fleksibilitas dan efektivitas penggunaan media interaktif semakin baik dari pertemuan ke pertemuan.

Hasil keterlaksanaan pembelajaran pada kelompok kontrol dapat dilihat pada tabel. 6 berikut. 
Tabel 6. Keterlaksanaan RPP pada Tiap-tiap Pertemuan di Kelompok Kontrol

\begin{tabular}{|c|c|c|c|c|c|}
\hline \multirow[b]{2}{*}{ No } & \multirow[b]{2}{*}{$\begin{array}{l}\text { Aspek yang } \\
\text { diobservasi }\end{array}$} & \multicolumn{2}{|c|}{ Skor keterlaksanaan media } & \multirow[b]{2}{*}{$\begin{array}{c}\text { Skor Rata- } \\
\text { rata } \\
\%\end{array}$} & \multirow[b]{2}{*}{ Kategor } \\
\hline & & $\begin{array}{c}\text { Aktivitas } \\
\text { peserta didik } \\
\%\end{array}$ & $\begin{array}{c}\text { Aktivitas } \\
\text { Guru } \\
\%\end{array}$ & & \\
\hline 1 & RPP 1 & 65 & 76 & 70,5 & cukup \\
\hline 2 & RPP 2 & 69 & 76 & 72,5 & cukup \\
\hline 3 & RPP 3 & 70 & 74 & 72 & cukup \\
\hline
\end{tabular}

Berdasarkan hasil pengamatan dan penelitian, proses pembelajaran di kelas kontrol cenderung berpusat pada guru. Peserta didik kurang aktif dan hanya mengerjakan apa yang diperintahkan guru sehingga pelaksanaan pembelajaran berlangsung monoton.

Keterlaksanaan pembelajaran pada kelompok kontrol berlangsung monoton. Pertemuan ke I aktivitas peserta didik $65 \%$, pertemuan ke II meningkat menjadi $69 \%$, meningkat lagi pada pertemuan ke III menjadi $70 \%$. Aktivitas guru pada pertemuan ke I $76 \%$, pertemuan ke II $76 \%$ dan pada pertemuan ke III menurun menjadi $74 \%$. Walaupun aktivitas peserta didik menunjukkan peningkatan, tetapi peningkatan itu tidak begitu berarti dan lebih cenderung monoton, hal ini diperjelas dari persentase keterlaksanaan RPP pada setiap pertemuan yang menunjukkan pada kriteria cukup.

\section{SIMPULAN}

Dari hasil penelitian yang telah dilakukan dapat disimpulkan bahwa pada pengukuran awal (pre test) menunjukkan hasil belajar siswa y ang belajar dengan media interaktif dengan peserta didik yang belajar dengan menggunakan media gambar tidak ada perbedaan. Tetapi setelah diberikan perlakuan di kelas eksperimen yaitu pembelajaran dengan media interaktif dan di kontrol yang diberikan perlakuan dengan media gambar, menunjukkan perbedaan hasil belajar yang signifikan. Hasil belajar di kelas eksperimen lebih baik bila dibandingkan dengan kelas yang menggunakan media gambar dilihat dari hasil post-test peserta didik

Hal ini membuktikan bahwa media interaktif yang diterima peserta didik pada saat pembelajaran cukup baik dan berpengaruh besar terhadap daya ingat dan pengetahuan siswa sehingga peserta didik dapat mengerjakan post test dengan lebih baik dibanding ketika mengerjakan pre test. Hasil belajar peserta didik di kelas kontrol dari hasil perhitungan nilai rata-rata pre test dan post test meningkat, namun peningkatannya tidak besar dibandingkan dengan kelas eksperimen disebabkan peserta didik menjawab bervariasi sesuai dengan sikapnya saat tes diberikan bukan akibat adany a perubahan perlakuan seperti yang terjadi di kelas eksperimen.

Hasil rata-rata uji gain di kelas yang menggunakan media interaktif lebih besar $(0,53)$ dibanding dengan rata-rata gain di kelas yang menggunakan media gambar $(0,48)$. Perbedaan ini menunjukkan bahwa pembelajaran dengan menggunakan media interaktif ternyata lebih baik dibanding dengan pembelajaran dengan menggunakan media gambar.

Begitu juga sikap cinta tanah air pada Pre-test dan Post-test di kelas eksperimen yang menggunakan media interaktif dan di kelas kontrol yang menggunakan media gambar menunjukkan peningkatan, tetapi peningkatan tersebut lebih baik di kelompok eksperimen bila dibandingkan dengan kelompok kontrol.

Dari penjelasan di atas dapat disimpulkan secara umum bahwa penggunaan media interaktif dapat meningkatkan hasil belajar dan sikap cinta tanah air peserta didik. Oleh karena itu penggunaan media interaktif pada materi kondisi fisik wilayah Indonesia merupakan pilihan y ang sangat bermanfaat dan memberikan hasil yang positif.

Berdasarkan hasil penelitian yang telah dilakukan maka dapat dikemukakan sran-saran y ang dapat bermanfaat bagi penulis atau peneliti selanjutnya, guru, dan sekolah sebagai berikut : 1) Media interaktif memperluas ketersediaan sumber belajar dan dapat dikembangkan apabila sekolah memiliki fasilitas lab komputer sehingga peserta didik 
memiliki kesempatan untuk memperoleh beragam sumber belajar; 2) Pemanfaatan media Interaktif menjadi alternatif dalam pembelajaran tema-tema yang berhubungan dengan kondisi fisik wilayah Indonesia dan cinta tanah air, sehingga media interaktif sebagai salah satu media pembelajaran yang cukup layak terutama dalam mengkongkritkan hal-hal yang masih abstrak; 3) Penggunaan media pembelajaran interaktif membutuhkan waktu yang lebih banyak sehingga diharapkan bagi guru agar dapat mengatur waktu sebaik-baiknya dan kontrol guru harus lebih tepat agar peserta didik tidak melakukan kegiatan lain atau membuka situs lain; 4) Tidak semua guru memiliki kemampuan dan kemauan untuk melakukan pembelajaran dengan media interaktif, untuk itu diharapkan kepada para guru yang belum memiliki kemampuan dan kemauan tersebut untuk meningkatkan kompetensinya.

\section{DAFTAR PUS TAKA}

Dahar, R. W. (2006). Teori-teori Belajar dan Pembelajaran. Jakarta. Erlangga..

Hamalik, O. (2001). Perencanaan Pengajaran Berdasarkan Pendekatan Sistem. Jakarta: Bumi Aksara.

Kemendiknas. (2010). Pengembangan Pendidikan Budaya dan Karakter Bangsa. Jakarta. Badan Penelitian dan Pengembangan Pusat Kurikulum

Maryani, E. (2006). Pendidikan Geografi (Ilmu dan Aplikasi Pendidikan). Bandung: UPI Press.

Rahayu dan Bagja W. (2011). Perbandingan Penggunaan Media Bagan dan Media Peta dalam Pembelajaran Geografi terhadap Pencapaian Kompetensi Dasar. Bandung; Jurnal Gea, Vol. 11, No 2.

Sagita, A (2011). Pengaruh Model Pembelajaran Berbasis Ict Terhadap Prestasi Belajar Siswa Pada Bidang Studi Matematika. (Online) Tersedia: http://www.google. co.id/url?sa=t\&rct=j\&q=\&esrc=s\&source=web\&cd=30\&cad=rja\&ved=0CFgQFjAJOB Q\&url=http $\% 3 \mathrm{~A} \% 2 \mathrm{~F} \% 2 \mathrm{Fmarlina}$.files.wordpress.com\%2F 2011\%2F03\%2Fproposalanggit-rancage-sagita.docx\&ei=WGaaULOvMorSrQfkk4H4Cw\&usg=AFQj CNHuhn YAdQ1WjOx3Bx6-oI5w6cj95g (15 Oktober 2012).

Sukmadinata, N. S. (2011). Metode Penelitian Pendidikan. Bandung. Remaja Rosdakarya.

Su'ud, Abu. (2006). Pendidikan IPS Sebagai Model Pendidikan Multikultural. Seminar Nasional Pendidikan IPS Sekolah Pasca Sarjana Universitas Pendidikan Indonesia. Bandung. ISBN :979. 15127-0-1.

Widiyati, Ana. (2011). Meningkatkan Hasil Belajar Geografi pada Materi Sejarah Pembentukan Bumi dengan KartuIndeks dan Media Film. Bandung; Jurnal Gea, Vol. 11 , No 2. 